\title{
EFFECTS OF HIBISCUS (Hibiscus sabdariffa L.) AND POPPY (Papaver thoeas L.) EXTRACTS ON DOUGH AND BREAD PROPERTIES
}

\author{
İlyas Çelik ${ }^{1}$, Ali Göncü ${ }^{2 *}$ \\ ${ }^{1}$ Pamukkale University, Faculty of Engineering, Department of Food Engineering, Denizli, Turkey. \\ ${ }^{2}$ Aydın Adnan Menderes University, Çine Vocational School, Department of Food Processing, Aydın, Turkey. \\ Received/ Geliş: 20.04.2021; Accepted/ Kabul: 14.09.2021; Published online/ Online bask1: 22.09.2021 \\ Celike, I., Göncü, A. (2021). Effects of hibiscus (Hibiscus sabdariffa L.) and popy (Papaver rboeas L.) extracts on dough and \\ bread properties the usage of bibiscus and poppy in bread. GIDA 46 (5) 1270-1278 doi: 10.15237/gida.GD21075
}

Çelik, İ., Göncü, A. (2021). Hibiskus (Hibiscus sabdariffa L.) ve gelincik (Papaver rboeas L.) ekstraktlarının ekmek hamuru ve ekmek özellikleri üzerine etkileri. GIDA 46 (5) 1270-1278 doi: 10.15237/gida.GD21075

\begin{abstract}
In this study, it was aimed to examine and compare the effects of Hibiscus (Hibiscus sabdariffa L.) and poppy (Papaver rhoeas L.) extracts on some chemical, physical, microbiological and sensory properties of bread dough and bread. The $\mathrm{pH}, L, b$, chroma, hue values of the dough decreased by usage of hibiscus extract, while the $a$ value was increasing. It was determined as the lowest $\mathrm{pH}$ was $4.13 ; L 39.23 ; b 5.08$; chroma was 6.55 , hue angle was 54.65 and the highest $a$ value was 7.20. Counts of total mesophilic aerobic bacteria and yeast/mold were found lower in dough with hibiscus extract. Hibiscus extract application gave the lowest specific volume value $(2.15 \mathrm{~mL} / \mathrm{g})$. In terms of hardness, gumminess and chewiness, the highest values were obtained in hibiscus bread as $24.96 \mathrm{~N}, 16.13 \mathrm{~N}$ and $147.86 \mathrm{mj}$, respectively. Sensory properties scored of the breads were lower than the control bread.
\end{abstract}

Keywords: Hibiscus, poppy, dough, bread, texture.

\section{HİBİSKUS (Hibiscus sabdariffa L.) VE GELINCİK (Papaver thoeas L.) EKSTRAKTLARININ EKMEK HAMURU VE EKMEK ÖZELLİKLERİ ÜZERİNE ETKILERİ}

ÖZ

Bu araştırma ile Hibiskus (Hibiscus sabdariffa L.) ve Gelincik (Papaver rhoeas L.) ekstraktlarının ekmek hamuru ve ekmeğin bazı kimyasal, fiziksel, mikrobiyolojik ve duyusal özellikleri üzerine etkilerinin incelenmesi amaçlanmıştır. Araştırma sonuçlarına göre, hibiskus ekstraktı hamurların $\mathrm{pH}, L, b$, kroma, hue açısı değerlerini düşürücü; $a$ değerini ise artırıcı etkide bulunmuştur. En düşük $\mathrm{pH}$ 4.13; $L$ 39.23; $b 5.08$; kroma 6.55 ve hue açıs1 54.65 olarak, en yüksek $a$ değeri ise 7.20 olarak belirlenmiştir. Hibiskus ekstraktlı hamurlarda toplam mezofilik aerobik bakteri ile maya ve küf sayısı düşük bulunmuştur. En düşük değerler sırasıyla, 7.09 ve $6.16 \mathrm{log} \mathrm{kob} / \mathrm{g}$ olarak belirlenmiştir. Ekmeklerde en düşük spesifik hacim değerini $(2.15 \mathrm{~mL} / \mathrm{g})$ hibiskus ekstraktı uygulaması vermiştir. Tekstürel özelliklerden sertlik, sakızımsılık ve çiğnenebilirlik değerlerinde hibiskus ekmeğinden diğer ekmeklere göre istatistiksel açıdan farklı sonuçlar alınmıştır. En yüksek değerler sırasıyla, $24.96 \mathrm{~N}, 16.13 \mathrm{~N}$ ve $147.86 \mathrm{mj}$ olarak elde edilmiştir. Ekstraktlı ekmeklerin duyusal skorları kontrol ekmeklerine göre daha düşük belirlenmiştir.

Anahtar kelimeler: Hibiskus, gelincik, hamur, ekmek, tekstür.

"Corresponding author / Yazışmalardan sorumlu yazar:

凶: ali.goncu@adu.edu.tr

(2): (+90) 2567117051

悬: (+90) 2567117054

ilyas Çelik; ORCID no: 0000-0002-8434-8797

Ali Göncü; ORCID no: 0000-0002-9676-1503 


\section{INTRODUCTION}

Hibiscus is a plant species that has more than 300 species in tropical and subtropical regions around the world. Hibiscus species is used as an ornamental plants, but it is believed that Hibiscus sabdariffa has also some medicinal properties (Qi et al., 2005). It is known by many names such as "Florida hibiscus", "Florida cranberry", "Roselle" and "Indian sorrel" in USA; "Asam silent", "Asama paya" and "Asam kumbang" in Malaysia; "Sorrel" or "Jamaican sorrel" in the Caribbean; "Karkade" or "Carcade" in Sudan and Egypt; "bisap" in Senegal and "Zobo" in Nigeria (Omemu et al., 2005; Mounigan and Badrie, 2007; Mohamed et al., 2012). In Turkey, "Okra flower" and "Mallow flower" known as hibiscus contain high vitamin $\mathrm{C}$ and anthocyanins. Nutritionists reported that $\mathrm{Ca}, \mathrm{K}, \mathrm{Mg}, \mathrm{Na}, \mathrm{Fe}$, niacin and riboflavin are high in hibiscus (Islam et al., 2016).

Hibiscus is an underused product that has quite good potential for medical and everday usage. Tea prepared with hibiscus has health benefits and it is rich with organic ingredients. It is a decaf herbal tea. Especially, tea is made from dried leaf. Hibiscus tea is a sweetened herbal tea and popular in Africa. The production of a soft drink from red hibiscus is very popular. It can be a suitable option for soft drinks industrially (Fellows and Axtell, 2014).

Hibiscus sabdariffa and Hibiscus rosasinensis are cardioprotective (hypocholesterolemic). Antioxidative and laptoprotective effects have been observed in animals (Olaleye, 2007). H.sabdariffa has been reported to be an antiseptic, aphrodisiac, digestive regulator and diuretic. It is also a folk remedy for abscess, biliary disease, cancer, cough, scurvy and cancer (Morton, 1987; Heyman, 2000). It is suggested that antibacterial effects of these plant extracts against E. coli, Pseudomonas aeruginosa and $S$. aureus have a significant therapeutic effect in the treatment of gastrointestinal infection and diarrhea in human skin diseases (Rogger et al., 1990).

Malva aegyptiaca L. plant, which belongs to the same family as hibiscus, is also frequently consumed in North Africa. It is also used in the treatment of dysentery and fevers. The leaves of this plant have also been tried in breads and successful results have been obtained (Fakhfakh et al., 2017).

Poppy, which is referred to as "Pavot Rouge" in French, "Gelincik" in Turkish, "Amapola" in Spanish and "Khash Khash" in Hindi are annual and red flowering plants that usually grow in crop fields and meadows. The syrup of the poppy flower is known as a sedative agent factor in some medicines in the field of medicine. It is used as a softener in diseases such as cough and cold. Chemical studies show that Papaver rhoeas extract persists rhoeadin, rhoeadic acid, papaveric acid, rhoeagenine, and anthocyanins as major compounds. $100 \mathrm{~g}$ dried poppy contains $15.33 \%$ ash and $22.75 \%$ protein (Pourmotabbeda et al., 2004; Kaya et al., 2004). Poppy is used both as a grain and as ground in many breads, breakfast snacks and cake, especially in North America (Lopez-Calleja et al., 2016). However, poppy sherbet is made from red leaves. Poppy syrup and jam are produced in Bozcaada, Turkey.

In this study, it is aimed to reveal the microbiological and physical effects of hibiscus and poppy extracts on dough and bread properties.

\section{MATERIALS AND METHODS Materials}

The poppies grown naturally in Denizli plateaus in spring were collected and their sepals were cut and dried under room conditions. Hibiscus which originated Sudan was obtained from the local market. Bread flour (İnceoğlu Flour Co.), drinking water, salt (Billur Salt Co.) and yeast (Pakmaya Yeast Co.) were used in bread making.

\section{Methods}

Preparation of extracts

$250 \mathrm{~g}$ of dry poppy and hibiscus were boiled in $1000 \mathrm{~mL}$ water for 20 minutes, then cooled down and filtered, to preparation of the extracts. The obtained extracts were stored in refrigerator conditions $\left(4^{\circ} \mathrm{C}\right)$ until use. 


\section{Bread making procedure}

Direct dough method (Elgün et al., 2012) was used with some modifications the production of Roll Bread. On the basis of flour (100 g), 57\% water, $2 \%$ fresh yeast and $1.5 \%$ salt were used in the control bread. In the production of other breads, instead of water, the obtained plant extracts water were used. The dough was obtained by kneading all the ingredients in a laboratory mixer (Kenwood) for 10 minutes. The remaining part, which was separated from the dough for analysis, was divided into $100 \mathrm{~g}$ doughs. The rounded doughs were first left to mass fermentation $\left(30{ }^{\circ} \mathrm{C}, 85 \%\right.$ moisture) for 30 minutes. After the mass fermentation, degassed doughs were left to the final fermentation $\left(30^{\circ} \mathrm{C}\right.$, $90 \%$ humidity) for 30 minutes by rolling process suitable for roll bread production. The doughs were baked at $220^{\circ} \mathrm{C}$ in a convection oven (ASL, Turkey) for 12 minutes and roll breads were obtained. In Figure 1, sample images of breads were indicated.

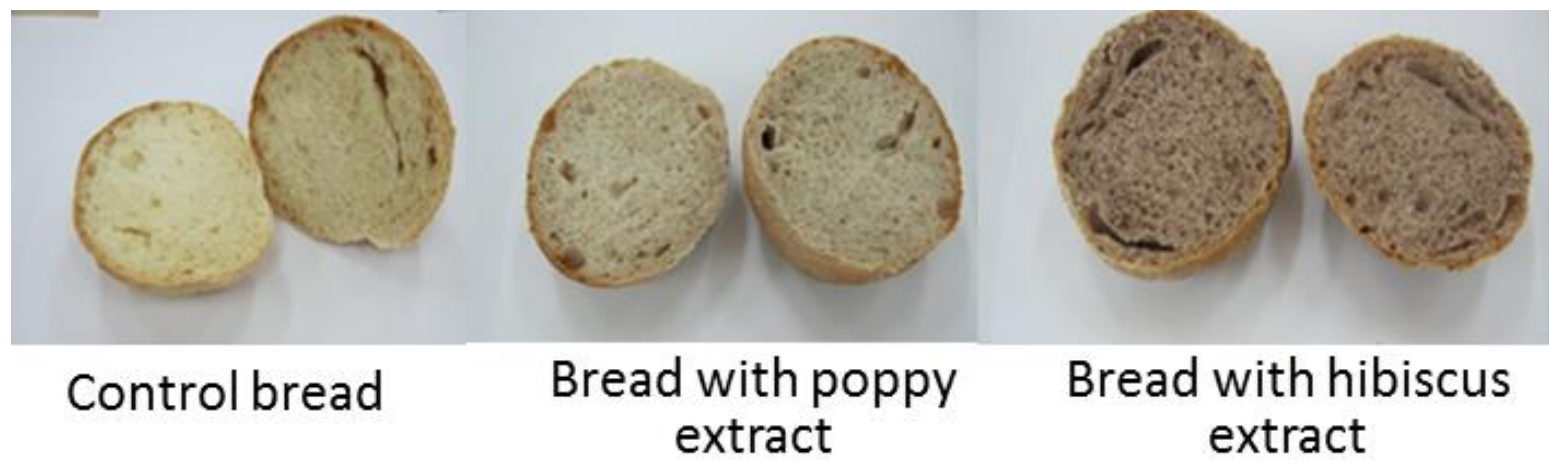

Figure 1. Cross-sectional views of roll breads.

\section{Physicochemical analyzes}

The $\mathrm{pH}$ value of the extract and dough was measured by pH-meter (Hanna Hl 8314) (Halkman, 2005). Hunter Lab color measurement device (Hunter Associates Laboratory, Model: MiniScan XE, USA) was used to determine the color properties of extract, dough and bread. Color measurements were made from 3 different points and evaluated by taking the average of the obtained values (Anonymous, 1995). " $L "$ value indicated brightness, "+a" value indicated redness, and " $+b "$ value indicates yellowness. Hunter $L, a$ and $b$ values obtained as a result of color measurements were not the color phenomena perceived directly by the buyer and seller in the market, so the "Hue Angle", which was the color tone angle (red-purple colors were at $0^{\circ}-270^{\circ}$ angle, color criteria such as yellow color at an angle of $60^{\circ}$, blue and green colors in the angle range of $240^{\circ}-120^{\circ}$ ) and "Chroma" value (indicate the saturation of the color, while the chroma value was decreasing in the dull colors, the chroma value increased in the vivid colors) respectively. It was calculated with by the help of equation 1 and 2;
Equation 1. Hue Angle $=\tan ^{-1}(b / a)$

Equation 2. Chroma $=\left(a^{2}+b^{2}\right)^{1 / 2}$

The dry matter in samples according to the method AACC 44-01.01 were determined (AACC, 1999). The volume of the breads was determined after one hour the end of baking using Equation 3 below.

Equation 3. Specific volume $(\mathrm{mL} / \mathrm{g})=$ Volume $(\mathrm{mL}) /$ Bread (g)

After weighing, the volume of the sample was measured by the rapeseed displacement method (Elgün et al., 2012).

\section{Textural analysis}

Texture profile analysis (TPA) of bread was performed using Brookfield CT3 4500 (England) texture analyzer and a $38.1 \mathrm{~mm}$ cylinder probe. After the roll breads were cut in the middle and made into $2 \mathrm{~cm}$ slices, reading was performed from by the inner surface. The device used by a speed of $1 \mathrm{~mm} / \mathrm{sec}$, a depth of $15 \mathrm{~mm}$ of 
immersion and an initial detection force of 4500 g. Hardness (N), resilience, adhesiveness (mj), springiness $(\mathrm{mm})$, gumminess $(\mathrm{N})$ and chewiness (mj) properties of breads were determined.

\section{Microbiological analyzes}

For the counting of total mesophilic aerobic bacteria (TMAB) and yeast/mold (YM) of the doughs, $10^{-5}, 10^{-6}$ and $10^{-7}$ concentrations of dilutions were planted according to the spreading method recpectively counting of TMAB and YM on PCA and DRBC media. TMAB count media were left to incubate (Nuve EN500) at $28^{\circ} \mathrm{C}$ for 3 days and for $\mathrm{YM}$ at $28{ }^{\circ} \mathrm{C}$ for 5 days (Landsborough, 2003).

\section{Sensory analysis}

In the sensory analysis of breads, 25 panelists were evaluated with a hedonic scale, with scores from 1 (Extremely Poor) to 7 (Excellent) in terms of color, smell, pore, texture, flavor and overall acceptability (Onoğur and Elmac1, 2011).

\section{Statistical analysis}

Statistical analysis were performed by the usage of analysis of variance with IBM SPSS Statistics 22 software. The differences between the averages were revealed by Duncan test (Arbuckle, 2020).

\section{RESULT AND DISCUSSION}

\section{Physicochemical properties}

The $\mathrm{pH}$ and color values of water, hibiscus and poppy extracts used in roll bread production were given in Table 1. Hibiscus extract showed acidic character, while poppy extract showed a neutral state. Organic acids which caused hibiscus to be acidic were malic acid $(0.29 \%)$, succinic acid $(0.08$ $\%)$, fumaric acid $(0.06 \%)$, acetic acid $(0.06 \%)$ and oxalic acid $(1.15 \%)$. With the effect of these acids, the $\mathrm{pH}$ value of hibiscus was stated as 2.5 (Hayashi and Seguchi, 1998). This was lower than the $\mathrm{pH}$ of the obtained hibiscus extract we obtained. The $\mathrm{pH}$ values of water and poppy extract were found to be statistically insignificant ( $p>0.05$ ). Kaya et al. (2004) reported the $\mathrm{pH}$ of the dried poppy as 5.87. It was understood that poppy extract was less acidic than hibiscus extract. Due to the penetration of the color pigments in the dried leaves into the water, hibiscus extract darkened the $L$ value by lowering, shifted the $a$ value from the green color region to the red color region and decreased the $b$ value more in hibiscus extract. There was also a decrease in the chroma value. However, the decrease was more in poppy extract. In terms of hue, poppy and hibiscus extracts had higher values than water had. Hayashi and Seguchi (1998) stated that hibiscus gave intense redness and so, when the hibiscus substitution increased, the redness values of the bread colors also increased. It is seen that the redness (a) value of the bread contained hibiscus extract was higher than the others. This result was seen in both bread dough color (Table 2) and crumb color (Table 5).

Table 1. pH and color values of water, hibiscus and poppy extracts.

\begin{tabular}{lcccccc}
\hline Samples & $\mathrm{pH}$ & $L$ & $a$ & $b$ & Chroma & Hue angle \\
\hline Water & $6.91 \pm 0.04 \mathrm{a}$ & $30.94 \pm 4.10 \mathrm{a}$ & $-1.31 \pm 0.16 \mathrm{~b}$ & $0.71 \pm 0.69 \mathrm{a}$ & $1.57 \pm 0.16 \mathrm{a}$ & $-26.99 \pm 5.80 \mathrm{~b}$ \\
\hline $\begin{array}{l}\text { Poppy } \\
\text { extract }\end{array}$ & $7.04 \pm 0.69 \mathrm{a}$ & $6.00 \pm 0.04 \mathrm{~b}$ & $0.45 \pm 0.12 \mathrm{a}$ & $0.37 \pm 0.08 \mathrm{~b}$ & $0.47 \pm 0.15 \mathrm{~b}$ & $18.57 \pm 5.08 \mathrm{ab}$ \\
\hline $\begin{array}{l}\text { Hibiscus } \\
\text { extract }\end{array}$ & $2.72 \pm 0.06 \mathrm{~b}$ & $5.56 \pm 0.48 \mathrm{~b}$ & $0.80 \pm 0.30 \mathrm{a}$ & $0.16 \pm 0.08 \mathrm{c}$ & $0.89 \pm 0.31 \mathrm{ab}$ & $25.29 \pm 3.43 \mathrm{a}$ \\
\hline
\end{tabular}

Each value is given as the mean of recurrence and parallel results and \pm standard deviation.

Values shown with different letters in the same column are statistically different from each other $(P<0.05)$.

The $\mathrm{pH}$ and color values of the obtained roll bread doughs were also given in Table 2. All the doughs samples showed acidic profile. Doughs which were obtained by using hibiscus extract had lower $\mathrm{pH}$ values. This was because hibiscus extract had a low $\mathrm{pH}$. The $\mathrm{pH}$ of bread doughs (Mata-Ramirez et al., 2018) made by substituting the Hibiscus powder 3-6-9\% increased in direct 
proportion to the substitution rate. While the dough $\mathrm{pH}$ of the control bread dough was 5.76, it decreased to 3.50 in those using $9 \%$ hibiscus powder. In the present study, the $\mathrm{pH}$ of the control dough was found to be 5.32 , while the $\mathrm{pH}$ of the hibiscus extract was 4.13. Considering the color values of the dough, the highest $L$ value was measured in control dough and the lowest was measured in hibiscus dough. The $a$ value was determined highest in hibiscus dough and lowest in the control dough. The $b$ value was also measured in the highest in control extract and the lowest in hibiscus extract as in the $L$ value. According to these results, while the lightest color and the highest yellowness value was in the control dough, it was the hibiscus dough with the darkest color and the least yellowness value. The highest redness value was determined in hibiscus dough, while the lowest was measured in control extract. Chroma and Hue angle values were found the highest in control extract, while the lowest were found in hibiscus extract.

Table 2. $\mathrm{pH}$ and color values of bread dough.

\begin{tabular}{lcccccc}
\hline Samples & $\mathrm{pH}$ & $\mathrm{L}$ & $a$ & $b$ & Chroma & Hue angle \\
\hline Control dough & $5.32 \pm 0.13 \mathrm{a}$ & $59.30 \pm 0.93 \mathrm{a}$ & $0.33 \pm 0.29 \mathrm{c}$ & $14.17 \pm 1.12 \mathrm{a}$ & $14.96 \pm 0,03 \mathrm{a}$ & $87.95 \pm 0,2 \mathrm{a}$ \\
\hline Poppy dough & $5.22 \pm 0,09 \mathrm{a}$ & $50.03 \pm 2,31 \mathrm{ab}$ & $2.29 \pm 1,42 \mathrm{~b}$ & $8.03 \pm 0,41 \mathrm{~b}$ & $7.84 \pm 0,02 \mathrm{~b}$ & $80.53 \pm 0,17 \mathrm{~b}$ \\
\hline Hibiscus dough & $4.13 \pm 0,27 \mathrm{~b}$ & $39.23 \pm 6,29 \mathrm{~b}$ & $7.20 \pm 4,80 \mathrm{a}$ & $5.08 \pm 0,37 \mathrm{c}$ & $6.55 \pm 0,02 \mathrm{c}$ & $54.65 \pm 0,25 \mathrm{c}$ \\
\hline
\end{tabular}

Each value is given as the mean of recurrence and parallel results and \pm standard deviation.

Values shown with different letters in the same column are statistically different from each other $(P<0.05)$.

Dry matter and specific volume values of breads were given in Table 3. According to the results, there was no statistically significant difference in terms of dry matter $(P>0.05)$. In terms of specific volume, it was determined that hibiscus breads had lower value, control and poppy breads had higher values and were statistically the same.

Table 3. Dry matter and specific volume values of breads

\begin{tabular}{lcc}
\hline Samples & Dry Matter $(\%)$ & Specific Volume $(\mathrm{mL} / \mathrm{g})$ \\
\hline Control bread & $60.35 \pm 0.83 \mathrm{a}$ & $3.48 \pm 0.55 \mathrm{a}$ \\
\hline Poppy bread & $59.18 \pm 0.44 \mathrm{a}$ & $3.46 \pm 0.64 \mathrm{a}$ \\
\hline Hibiscus bread & $58.85 \pm 0.77 \mathrm{a}$ & $2.15 \pm 0.40 \mathrm{~b}$ \\
\hline
\end{tabular}

Each value is given as the mean of recurrence and parallel results and \pm standard deviation.

Values shown with different letters in the same column are statistically different from each other $(P<0.05)$.

According to the farinograph results of the dough produced by substituting the hibiscus flour with wheat flour at $1 \%$ and $5 \%$ ratios, it showed that the acids in hibiscus had some effect on the kneading behavior of the wheat flour dough. It was stated that the consistency of the dough decreases especially with acidity (Hayashi and Seguchi, 1998). The reason why the specific volume was lower in hibiscus bread is the weakening of gluten bonds and the decrease in gas holding capacity due to the decrease in dough $\mathrm{pH}$. In addition, hibiscus seeds contain high levels of dietary fiber (soluble: $11.2-12.1 \%$; insoluble: $28.3-$ $30.5 \%$ and total dietary fiber: $39.5-42.6 \%$ ) (Hainida et al., 2008) likewise so this caused the weakening of the gluten bonds and reduced gas holding capacity, resulting in a lower specific volume. Hayashi and Seguchi (1998) produced breads by replacing hibiscus flour with wheat flour in various proportions up to $10 \%$ and measured their specific volumes. They reported that the specific volume $\left(\mathrm{cm}^{3} / \mathrm{g}\right)$ decreased as the rate of substitution increased (except 10\% substitution). While the specific volume of the control bread was 3.68, it was reported that it decreased to 1.64. Besides, it was stated that the $\mathrm{pH}$ value dropped from 5.42 to 3.35 . In the same study, when the $\mathrm{pH}$ was kept at the level of the control bread, the specific volume values of the breads increased a lot, and even more volume was 
obtained in those with 1-2-3\% substitution than the control breads. In a study conducted by Abdulla and Abdel-Samie (2015), it was reported that the specific volume $\left(\mathrm{g} / \mathrm{cm}^{3}\right)$ decreased (from 2.83 to 2.47 ) while the substitution ratio was increasing, similarly, in the basing it happened mainly where the hibiscus seed flour is replaced at $5-10-15 \%$. In addition, as the substitution rate increased, it was determined that the water holding capacity (\%) and dough stability (minute) decreased and the dough development time (minute) increased according to the Mixolab results. In a similar study (Mata-Ramirez et al., 2018), breads were produced with 3-6-9\% hibiscus powder substitution, and as a result of the study, it was found that dough height, bread height, oven splash and bread volume decreased and water holding capacity decreased due to the increase in the substitution ratio. It was stated that kneading time and bread weight increased.

The crust color values of bread samples can be seen in Table 4. There was no difference $(p>0.05)$ between breads in terms of the lightness-darkness $(L)$ values of the crust colors. However, while the lowest value in $a$ and $b$ values was measured in hibiscus breads, the highest values were observed in control and poppy breads. Like with in the $L$ value, there was no difference between the samples in chroma and Hue angle values. Although the brightness was in the highest in control bread according to the chroma value, there was no statistically significant difference $(p>0.05)$ between breads. Likewise As the same, although the highest value in Hue angle was in hibiscus bread, no statistically significant difference $(p>0.05)$ was found.

Table 4. Crust color values of breads

\begin{tabular}{lccccc}
\hline Samples & $L$ & $a$ & $b$ & Chroma & Hue angle \\
\hline Control bread & $37.15 \pm 2.82 \mathrm{a}$ & $10.16 \pm 2.23 \mathrm{a}$ & $14.06 \pm 0.07 \mathrm{a}$ & $60.45 \pm 0.79 \mathrm{a}$ & $88.45 \pm 0.12 \mathrm{a}$ \\
\hline Poppy bread & $39.94 \pm 3.41 \mathrm{a}$ & $9.77 \pm 0.02 \mathrm{ab}$ & $14.61 \pm 1.23 \mathrm{a}$ & $59.29 \pm 0.41 \mathrm{a}$ & $88.56 \pm 0.13 \mathrm{a}$ \\
\hline Hibiscus bread & $42.80 \pm 0.75 \mathrm{a}$ & $5.37 \pm 1.265 \mathrm{~b}$ & $9.62 \pm 2.72 \mathrm{~b}$ & $58.89 \pm 0.06 \mathrm{a}$ & $88.66 \pm 0.03 \mathrm{a}$ \\
\hline
\end{tabular}

Each value is given as the mean of recurrence and parallel results and \pm standard deviation.

Values shown with different letters in the same column are statistically different from each other $(P<0.05)$.

Crumb color values of breads were given in Table 5. It was seen that while the $L, b$, chroma and hue angle values of the control breads were determined as the highest, they also had the lowest $b$ value. In terms of crumb color, the ones with the darkest $(L)$ color and the highest redness value (a) were the hibiscus breads. Breads with the highest yellowness value (b) were the control breads. Poppy breads and hibiscus breads were similar in terms of $a, b$, chroma and hue angle values. Mata-Ramirez et al. (2018) also reported the color values of hibiscus powder substituted breads $(0-3-6-9 \%)$ in direct proportion to the substitution rate as follows: L: 50,58 - 24.39, a: 9.70 - 6.12, b: 30.28 - 15.15, chroma: 31.80 - 16.34 and hue angle: $72.22-68.00$. When the results were compared with the crumb color values of the hibiscus bread, in both studies, it was seen that the $L$ value decreased, the $a$ value increased and the $b$ value decreased compared to the control. While the obtained $L$ and hue angle values were found to be higher among the values rates in the studies, $a, b$ and chroma values were lower. The main reason for these differences is that hibiscus powder was used in the studies instead of hibiscus extract in studies.

Table 5. Crumb color values of breads

\begin{tabular}{lccccc}
\hline Samples & $L$ & $a$ & $b$ & Chroma & Hue angle \\
\hline Control bread & $56.03 \pm 0.86 \mathrm{a}$ & $0.14 \pm 0.02 \mathrm{~b}$ & $12.61 \pm 0.03 \mathrm{a}$ & $12.61 \pm 0,04 \mathrm{a}$ & $89.36 \pm 0.06 \mathrm{a}$ \\
\hline Poppy bread & $44.83 \pm 1.20 \mathrm{~b}$ & $1.64 \pm 0.47 \mathrm{ab}$ & $7.85 \pm 0.84 \mathrm{~b}$ & $8.03 \pm 0.72 \mathrm{~b}$ & $77.98 \pm 4.53 \mathrm{ab}$ \\
\hline Hibiscus bread & $35.40 \pm 2.89 \mathrm{c}$ & $4.65 \pm 1.66 \mathrm{a}$ & $6.29 \pm 1.06 \mathrm{~b}$ & $7.95 \pm 0.13 \mathrm{~b}$ & $53.66 \pm 14.32 \mathrm{~b}$ \\
\hline
\end{tabular}

Each value is given as the mean of recurrence and parallel results and \pm standard deviation.

Values shown with different letters in the same column are statistically different from each other $(P<0.05)$. 


\section{Textural properties}

The results of the TPA values of the breads were given in Table 6 . According to the results, there was no difference between breads in spring, adhesiveness and springiness values. However, hibiscus breads had higher values in terms of hardness, gumminess and chewiness. The reason for this was that the textural properties of hibiscus breads were negatively affected due to the decrease in specific volume values (Table 3). There was no difference in any parameter in terms of textural properties in control and poppy breads. Abdulla and Abdel-Samie (2015) reported in their study that the hardness, adhesiveness, chewiness and flexibility values increased as the substitution rate increased in the basmages where hibiscus seed flour was substituted at the rate of 5-10-15\%. Likewise, Mata-Ramirez et al. (2018) also reported that the adhesiveness, hardness and chewiness characteristics of hibiscus powdersubstituted breads (3-6-9\%) increased in direct proportion with the increase in the rate of substitution. Hardness, gumminess and chewiness values were determined more than the control in the breads we obtained.

Table 6. TPA values of breads.

\begin{tabular}{lcccccc}
\hline Samples & Hardness (N) & Resilience & Adhesiveness $(\mathrm{mj})$ & Springiness $(\mathrm{mm})$ & Gumminess $(\mathrm{N})$ & Chewiness (mj) \\
\hline $\begin{array}{l}\text { Control } \\
\text { bread }\end{array}$ & $5.45 \pm 0.02 \mathrm{~b}$ & $0.55 \pm 0.04 \mathrm{a}$ & $0.81 \pm 0.07 \mathrm{a}$ & $9.26 \pm 0.42 \mathrm{a}$ & $4.56 \pm 0.60 \mathrm{~b}$ & $42.43 \pm 7.60 \mathrm{~b}$ \\
\hline $\begin{array}{l}\text { Poppy } \\
\text { bread }\end{array}$ & $4.89 \pm 1.88 \mathrm{~b}$ & $0.55 \pm 0.06 \mathrm{a}$ & $0.80 \pm 0.06 \mathrm{a}$ & $9.02 \pm 0.18 \mathrm{a}$ & $3.88 \pm 1.18 \mathrm{~b}$ & $35.07 \pm 11.41 \mathrm{~b}$ \\
\hline $\begin{array}{l}\text { Hibiscus } \\
\text { bread }\end{array}$ & $24.96 \pm 4.39 \mathrm{a}$ & $0.41 \pm 0.01 \mathrm{a}$ & $0.67 \pm 0.01 \mathrm{a}$ & $9.27 \pm 0.13 \mathrm{a}$ & $16.13 \pm 1.84 \mathrm{a}$ & $147.86 \pm 18.40 \mathrm{a}$ \\
\hline
\end{tabular}

Each value is given as the mean of recurrence and parallel results and \pm standard deviation.

Values shown with different letters in the same column are statistically different from each other $(P<0.05)$.

\section{Microbiological properties}

The microbiological results of the roll bread doughs produced were given in Table 7. TMAB and YM counts were performed as microbiological analysis. According to the obtained results obtained, the highest TMAB and YM count was found in control dough and the lowest in hibiscus dough. This case was related to the $\mathrm{pH}$ degrees of the doughs. Microbial growth was more limited with high acidity in hibiscus dough with the lowest $\mathrm{pH}$. Since the $\mathrm{pH}$ was high in the control dough, microbial growth was higher due to the same reason.

Table 7. Microbiological results of bread dough $(\log \mathrm{cfu} / \mathrm{g})$.

\begin{tabular}{lcc}
\hline Samples & TMAB & YM \\
\hline Control dough & $7.40 \pm 0.06 \mathrm{a}$ & $7.34 \pm 0,09 \mathrm{a}$ \\
\hline Poppy dough & $7.27 \pm 0.09 \mathrm{ab}$ & $7.18 \pm 0.06 \mathrm{a}$ \\
\hline Hibiscus dough & $7.09 \pm 0.02 \mathrm{~b}$ & $6.16 \pm 0.07 \mathrm{~b}$ \\
\hline
\end{tabular}

Each value is given as the mean of recurrence and parallel results and \pm standard deviation.

Values shown with different letters in the same column are statistically different from each other $(P<0.05)$.

\section{Sensory properties}

The sensory analysis results of the breads were given in Table 8 . When the breads were examined in terms of their sensory properties, no difference was observed between them each other in terms of smell. Control bread got the highest scores in terms of color, pores, texture and taste. Hibiscus bread got the lowest scores in terms of texture. The lowest specific volume (Table 4) and TPA
(Table 7) results also supported this. According to the general taste scores, the most popular breads were control and hibiscus breads. Both breads scored good and above good, while the poppy bread scored above the average. According to the sensory analysis results, although even dough hibiscus breads scored higher than poppy breads, both hibiscus and poppy breads were appreciated. 
Table 8. Sensory analysis values of breads.

\begin{tabular}{lcccccc}
\hline Samples & Color & Smell & Pore & Texture & Flavor & $\begin{array}{c}\text { Overall } \\
\text { acceptability }\end{array}$ \\
\hline Control bread & $6.05 \pm 0.28 \mathrm{a}$ & $5.69 \pm 0.27 \mathrm{a}$ & $6.20 \pm 0.28 \mathrm{a}$ & $5.80 \pm 0.14 \mathrm{a}$ & $6.25 \pm 0.07 \mathrm{a}$ & $5.95 \pm 0.21 \mathrm{a}$ \\
\hline Poppy bread & $5.46 \pm 0.09 \mathrm{ab}$ & $5.31 \pm 0.02 \mathrm{a}$ & $5.50 \pm 0.14 \mathrm{~b}$ & $5.25 \pm 0.21 \mathrm{~b}$ & $5.25 \pm 0.06 \mathrm{c}$ & $4.85 \pm 0.21 \mathrm{~b}$ \\
\hline Hibiscus bread & $5.20 \pm 0.28 \mathrm{~b}$ & $5.43 \pm 0.02 \mathrm{a}$ & $5.25 \pm 0.07 \mathrm{~b}$ & $4.70 \pm 0.14 \mathrm{c}$ & $5.65 \pm 0.07 \mathrm{~b}$ & $5.60 \pm 0.14 \mathrm{a}$ \\
\hline
\end{tabular}

Each value is given as the mean of recurrence and parallel results and \pm standard deviation.

Values shown with different letters in the same column are statistically different from each other $(P<0.05)$.

In the studies of Abdulla and Abdel-Samie (2015), it was stated that as the substitution rate increased in the basmages where hibiscus seed flour was substituted by $5-10-15 \%$, it got less points from the sensory characteristics in terms of flavor, bread crust color, bread crumb color, uniformity, taste and overall acceptability. Mata-Ramirez et al. (2018) examined the odor, texture, flavor, color and total acceptability characteristics of hibiscus powder-substituted breads (3-6-9\%). According to the results, he got the highest scores in from the best odor, color and total acceptability in control breads. In terms of texture and flavor, it was observed that breads with 3\% substitution ratio got the highest scores.

\section{CONCLUSIONS}

In the research, production of hibiscus and poppy breads was carried out and some of their properties were investigated. According to overall acceptability sensory property, more positive result were obtained from hibiscus roll bread than poppy bread. According to the structural properties, poppy breads were observed to be better. For instance, hibiscus breads were found to be firmer (hardness) than poppy breads. In addition, poppy breads was determined the same specific volume value as the control bread, while hibiscus was determined lower. In order to eliminate these structural problems seen in hibiscus breads, the $\mathrm{pH}$ of hibiscus extract must be adjusted to neutral by using components such as carbonate. In this case and if it is adjusted, it can say that the structural negativities will disappear and the bitter taste, which is unique to the poppy, is welcomed by the panalists.

\section{CONFLICT OF INTEREST}

There is no conflict of interest between the authors and with other persons and / or institutions related to this article.

\section{AUTHORSHIP CONTRIBUTION}

İlyas Çelik and Ali Göncü contributed equally to the entire study.

\section{REFERENCES}

AACC. (1999). Approved Methods of Analysis. 11th ed. Method 44-01.01. Moisture - Calculation of Percent Moisture.

Abdulla, G. and Abdel-Samie, M. A. S. (2015). Effect of Roselle Seeds Flour Addition on the Quality Characteristics of Pan Bread. J. Dairy Sci., 6(11), 625-636.

Anonymous, (1995). "The Manual of Hunter-Lab Mini Scan XE Colorimeter”, Virginia: HunterLab Cooperation, U.S.A.

Arbuckle, J.L. (2020). IBM SPSS statistics 22 For Windows. User's Guide. ftp://public.dhe.ibm.com/software/analytics/sp ss/documentation/amos/22.0/en/Manuals/IB M_SPSS_Amos_User_Guide.pdf (Accessed: 10.06.2020).

Elgün, A, Certel, M, Ertugay, Z, Kotancilar, H. G. (2012). Tahıl ve ürünlerinde analitik kalite kontrolü ve laboratuar uygulama k1lavuzu. Atatürk Üniversitesi Ziraat Fakültesi Yaymlar, No:335, 245 s (In Turkish).

Fakhfakh, N., Jdir, H., Jridi, M., Rateb, M., Belbahri, L., Ayadi, M. A., Nasri, M., Zouari, N. (2017). The mallow, Malva aegyptiaca L.(Malvaceae): phytochemistry analysis and 
effects on wheat dough performance and bread quality. LWT - Food Sci Technol, 75, 656-662.

Fellows, P.J., Axtell, B. (Eds). (2014). Opportunities in Food Processing: A handbook for setting up and running a smallscale business producing high-value foods. ACP-EU Technical Centre for Agricultural and Rural Cooperation (CTA). Wageningen, The Netherlands, pp 454.

Halkman, A.K. 2005. Gida Mikrobiyolojisi Uygulamaları. Başak Matbaacilk. 358. (In Turkish).

Hainida, K. E., Amin, I., Normah, H., and Esa, N. M. (2008). Nutritional and amino acid contents of differently treated Roselle (Hibiscus sabdariffa L.) seeds. Food chem., 111(4), 906-911.

Hayashi, M., and Seguchi, M. (1998). IronEnriched Bread with Karkade (Hibiscus sabdariffa) and Wheat Flour. Cereal chem., 75(5), 686-689.

Heyman, M. (2000). Effect of lactic acid bacteria on diarrheal diseases. J Am Coll Nutr, 19: 137S$146 \mathrm{~S}$.

Islam, A, Jamini, T.S, Islam M. and Yeasmin, S. (2016). Roselle: A Functional Food with High Nutritional and Medicinal Values. Fundam. appl. agric., 1(2): 44-49.

Kaya, İ., İncekara, N. and Nemli, Y., (2004), Ingredients of Some Weeds Consumed As Food in Aegean Region, J. Agric. Sci., 14(1): 1-6.

Landsborough, L. (2003). Food Microbiology Laboratory (Contemporary Food Science). CRC Press. ISBN-13: 978-0849312670.p 196.

López-Calleja, I. M., de la Cruz, S., González, I., García, T., and Martín, R. (2016). Duplex realtime PCR using TaqMan ${ }^{\circledR}$ for the detection of sunflower (Helianthus annuus) and poppy (Papaver rhoeas) in commercial food products. LWT - Food Sci Technol., 65, 999-1007.

Mata-Ramírez, D., Serna-Saldívar, S. O., VillelaCastrejón, J., Villaseñor-Durán, M. C., and Buitimea-Cantúa, N. E. (2018). Phytochemical profiles, dietary fiber and baking performance of wheat bread formulations supplemented with
Roselle (Hibiscus sabdariffa). J. Food Meas. Charact., 12(4), 2657-2665.

Mohamed, B.B., Sulaiman, A.A., Dahab, A.A. (2012). Roselle (Hibiscus sabdariffa L.) in Sudan, Cultivation and Their Uses. Bullet Environ Pharmacol Life Sci, 1(6): 48 - 54.

Morton, J.F. (1987). Roselle. In: fruits of warm climate, (CF Dowling (ed)). Media, Inc. Greensboro, NCP. pp. $281-286$.

Mounigan, P. and Badrie, N. (2007). Physicochemical and Sensory Quality of Wines from Red Sorrel/Roselle (Hibiscus Sabdariffa L) Calyces: Effects of Pretreatments of Pectolase and Temperature/Time, Int. J. Food Sci., 42, 469475.

Olaleye, M. T. (2007). Cytotoxicity and antibacterial activity of Methanolic extract of Hibiscus sabdariffa. Res. J. Med. Plant., 1(1): 009013.

Omemu, A.M., Edema, M.O., Atayese, A.O. and Obadina, A.O. (2005). A survey of the Microflora of Hibiscus Sabdariffa (Roselle) and the resulting Zobo Juice, Afr. J. Biotechnol., 5 (3), 254-259.

Onoğur, A.T, Elmaci, Y. (2011). Gidalarda Duyusal Değerlendirme, Ege Üniversitesi Mühendislik Fakültesi G1da Mühendisliği Bölümü, Bornava-İZMIR, Yayın no: 010-1B, ISBN:978-9944-5660-8-7. 66 s. (In Turkish).

Pourmotabbeda, A., Rostamiana, B., Manouchehria, G., Pirzadeh-Jahromib, G., Sahraeib, H., Ghoshoonib, H., Zardoozc, H. and Kamalnegad, M. (2004). Effects of Papaver rhoeas extract on the expression and development of morphine-dependence in mice. $J$. Ethnopharmacol., 95:431-435.

Rogger, Y.S., John, L.I., Mark, L.W. (1990). General Microbiology. 5th ed. Macmillan education Ltd, London, pp. 626-642.

Qi, Y., Chin, K.L., Malekian, F., Berhane, M., and Gager, J. (2005). Biological Characteristics, Nutritional and Medicinal Value of Roselle, Hibiscus Sabdariffa. CIRCULAR - Urban Forestry Natural Resources and Environment No. 604. 